\title{
PENGARUH MODEL CORE TERHADAP HASIL BELAJAR MATEMATIKA DITINJAU DARI KEMAMPUAN BERPIKIR KRITIS PESERTA DIDIK KELAS V GUGUS 02 KUTA UTARA
}

\author{
K.A. Kasmita ${ }^{1}$, I.M. Ardana ${ }^{2}$, I.M. Gunamantha ${ }^{3}$ \\ ${ }^{123}$ Program Studi Pendidikan Dasar \\ Universitas Pendidikan Ganesha \\ Singaraja, Indonesia \\ e-mail: ayukasmita93@yahoo.com¹, ardana@undiksha.ac.id², \\ made.gunamantha@undiksha.ac.id ${ }^{3}$
}

\begin{abstract}
Abstrak
Penelitian ini bertujuan untuk mengetahui pengaruh model Core terhadap hasil belajar matematika ditinjau dari kemampuan berpikir kritis peserta didik. Penelitian ini adalah penelitian eksperimen semu dengan rancangan faktorial $2 \times 2$. Populasi penelitian adalah seluruh siswa kelas $\mathrm{V}$ sebanyak 233 orang siswa. Sampel pada penelitian ini berjumlah 76 orang siswa. Data kemampuan berpikir kritis dan hasil belajar matematika dikumpulkan dengan tes. Data dianalisis dengan menggunakan analisis Anava AB berbantuan SPSS 17.00 for windows. Hasil penelitian menunjukkan bahwa: 1) terdapat pengaruh yang signifikan implementasi Model CORE terhadap hasil belajar matematika 2) terdapat pengaruh interaksi yang signifikan Model CORE dengan kemampuan berpikir kritis terhadap hasil belajar matematika, 3) pada kelompok peserta didik yang memiliki kemampuan berpikir kritis tinggi, terdapat pengaruh yang signifikan implementasi Model CORE terhadap hasil belajar matematika, dan 4) pada kelompok peserta didik yang memiliki kemampuan berpikir kritis rendah, terdapat pengaruh yang signifikan implementasi Model CORE terhadap hasil belajar matematika.
\end{abstract}

Kata kunci: Hasil Belajar Matematika; Kemampuan Berpikir Kritis; Model Core

\begin{abstract}
This study aims to determine the effect of the Core model on mathematics learning outcomes in terms of students' critical thinking skills. This research is a quasi-experimental research with $2 \times 2$ factorial design. The study population was all fifth grade students as many as 233 students. The sample in this study amounted to 76 students. Data on critical thinking skills and mathematics learning outcomes were collected by tests. Data were analyzed using Anava AB analysis assisted by SPSS 17.00 for windows. The results showed that: 1) there was a significant influence on the implementation of the CORE Model on mathematics learning outcomes 2) there was a significant interaction effect on the CORE Model with critical thinking skills on mathematics learning outcomes, 3) on groups of students who had high critical thinking skills, there were a significant effect of the implementation of the CORE Model on mathematics learning outcomes, and 4) in groups of students who have low critical thinking skills, there is a significant effect of the implementation of the CORE Model on mathematics learning outcomes.
\end{abstract}

Keywords: Mathematics Learning Outcomes; Critical Thinking Skills; Core Models 


\section{PENDAHULUAN}

Kurikulam 2013 yang lebih menekankan pada aspek sikap, menurut guru masih banyak karakter sikap peserta didik yang masih kurang, yaitu: 1) sikap percaya diri peserta didik terlihat saat pembelajaran berlangsung peserta didik masih malu-malu saat menjawab, 2) sikap tanggung jawab terlihat saat kegiatan belajar mengajar berlangsung peserta didik asik main sendiri, mengabaikan pembelajaran, dan saat mendapatkan tugas dari guru peserta didik sering mengabaikan tugas dari guru, 3) Kerjasama, dalam sikap ini telihat saat peneliti melakukan observasi saat kegiatan berlangsung, peserta didik masih cenderung untuk belajar secara mandiri, 4) Dari jawaban guru saat wawancara sikap peduli peserta didik dalam pembelajaran juga masih kurang terlihat saat peserta didik dalam belajar kelompok, peserta didik tidak peduli dengan teman satu kelompoknya, dan juga tidak peduli terhadap apa yang dikerjakan oleh kelompoknya, 5) Rasa ingin tahu peserta didik terlihat saat guru menjelaskan materi peserta didik masih pasif terhadap penjelasanyang diberikan oleh guru. Penerapan pendidikan didasarkan pada sebuah kurikulum. Kurikulum ialah suatu perangkat rencana pendidikan untuk mencapai tujuan pendidikan itu sendiri. Kurikulum terbaru yang saat ini digunakan dalam pelaksanaan kegiatan pembelajaran di Indonesia adalah Kurikulum 2013.

Belajar menurut Dimyati (2006:250) hasil belajar merupakan proses belajar, peserta didik sebagai pelaku aktif dalam belajar dan guru sebagai pelaku aktif pembelajaran. Menurut Tu'u (2004) hasil belajar adalah yang dicapai peserta didik ketika mengikuti dan mengerjakan tugas dan kegiatan pembelajaran di sekolah. Hasil belajar ditunjukan melalui nilai atau angka nilai dari hasil evaluasi yang dilakukan oleh guru terhadap tugas peserta didik dan ulangan-ulangan atau ujian yang ditempuh.Menurut Poerwardaminto (2004) hasil belajar yang dicapai seseorang setelah melakukan suatu kegiatan belajar yang berupa nilai dari hasil belajar yang diberikan oleh guru. Hasil belajar seseorang selama proses pembelajaran akan dapat dilihat dari nilai yang dicapai.

Nilai yang diproleh merupakan nilai dari hasil tes maupun sikap seseorang selama belajar yang diberikan oleh guru. Hasil belajar seseorang selama proses pembelajaran akan dapat dilihat dari nilai yang dicapai. Nilai yang diproleh merupakan nilai dari hasil tes maupun sikap seseorang selama belajar yang diberikan oleh guru. Dari beberapa pendapat di atas, peneliti dapat menyimpulkan bahwa hasilbelajar adalah suatu hasil atau perubahan tingkah laku yang telah dicapai dari proses belajar mengajar yang dilakukan oleh guru dan hasil belajar dinilai dengan ukuran guru tingkat sekolah dan tingkat nasional.

Terkait dengan peningkatan pembelajaran matematika, mengapa menjadi sangat penting ditingkatkan oleh guru. Salah satu alasannya adalah karena matematika merupakan ilmu dasar, sehingga dalam pembelajaran di sekolah harus memperhatikan perkembanganperkembangan yang terjadi masa lalu dan di masa sekarang (Suherman, 2001). Dalam pendidikan matematika di Indonesia dikenal istilah matematika sekolah yaitu matematika yang diajarkan di sekolah (Suherman, 2003:55). Dalam pembelajaran matematika di sekolah dibutuhkan strategi yang tepat yaitu dengan menerapkan berbagai macam model pembelajaran. Terdapat berbagai pendekatan, metode atau strategi, maupun model pembelajaran yang dapat diterapkan dalam proses pembelajaran di sekolah. Guru dapat memilih model pembelajaran sesuai dengan tujuan yang akan dicapai. Salah satunya dapat dilakukan melalui penggunaan model pembelajaran yang banyak melibatkan peserta didik aktif dalam pembelajaran, baik secara mental, fisik, sosial, serta yang sesuai dengan situasi sehingga tujuanpembelajaran yang direncanakan akan tercapai (Suherman, 2001:60).

Abad 21 merupakan era digital yang ditandai dengan pesatnya perkembangan teknologi dan informasi. Perkembangan teknologi dan informasi ini mempengaruhi segala aspek kehidupan, tak terkecuali bidang pendidikan, dimana teknologi menjadi bagian yang integral dengan 
kehidupan pebelajar. Pesatnya perkembangan zaman ini juga berbanding lurus dengan perkembangan masalahmasalah yang dihadapi, dimana masalahmasalah yang timbul menjadi semakin kompleks dan diperlukan sumber daya manusia yang mampu menghadapi masalah-masalah tersebut. Oleh karena itu, pendidikan pada abad ini dituntut untuk menghasilkan sumber daya manusia yang berkualitas unggul yang mampu menghadapi tantangan global abad 21. Akibatnya, pendidikan pada abad ini menjadi semakin penting untuk menjamin peserta didik memiliki keterampilan belajar dan berinovasi, keterampilan menggunakan teknologi dan media informasi, serta dapat bekerja, dan bertahan dengan menggunakan keterampilan untuk hidup (life skills) (Trilling \& Fadel, 2009: 48). 2 Salah satu isu vital pendidikan pada abad 21 ini adalah mengembangkan kemampuan berpikir tingkat tinggi (high order thinking) peserta didik.

Berpikir kritis adalah suatu berpikir dengan tujuan membuat keputusan masuk akal tentang apa yang diyakini atau dilakukan. Berpikir kritis merupakan kemampuan menggunakan logika. Logika merupakan cara berpikir untuk mendapatkan pengetahuan yang disertai pangkajian kebenaran berdasarkan pola penalaran tertentu. Selanjutnya ada enam dalam berpikir kritis, yang disingkat dengan FRISC), yaitu Focus( fokus), Reason (alasan), Inference (menyimpulkan), Situation (situasi), Clarity (kejelasan), dan Overview (pandangan menyeluruh) menurut Ahmad Susanto (2013).Berpikir kritis merupakan salah satu kemampuan berpikir tingkat tinggi. Berpikir kritis adalah sebuah proses sistematis yang memungkinkan peserta didik merumuskan dan mengevaluasi keyakinan dan pendapat mereka sendiri yang didasarkan pada nilai intelektual universal yang melampaui uraian pokok perdoalan kedalam kejelasan, ketepatan, akurasi, presisi, konsistensi, relevansi, bukti yang memadai, nalar yang baik, kedalaman, dan faimess (Suprijono, 2016: 42). Pendapat tersebut sejalan dengan Gunawan (2003:177) yang menyatakan bahwa keterampilan berpikir kritis adalah kemampuan untuk berpikir pada level yang kompleks dan menggunakan proses analisis dan evaluasi. Ennis (2011) menyatakan bahwa berpikir kritis adalah pemikiran yang rasional dan reflektif yang terfokus pada memutuskan apa yang harus dipercaya atau lakukan. Dalam memutuskan apa yang akan dipercaya dan dilakukan, diperlukan informasi yang reliabel dan pemahaman terhadap topik yang dihadapi. Selain itu, Gokhale (1995) menyatakan bahwa yang dimaksud dengan berpikir kritis adalah aktivitas yang melibatkan analisis, sintesis, dan evaluasi dari suatu konsep. Berpikir kritis dicirikan oleh kemampuan analisis yaitu kemampuan menguraikan suatu materi menjadi komponen-komponennya. Kemampuan ini antara lain mengidentifikasi bagian informasi, menganalisis hubungan antar bagian, dan mengenali prinsip yang ada di dalamnya (Suprijono, 2016: 32).

Salah satu kemampuan high order thinking yang dituntut untuk diasah pada abad 21 adalah kemampuan berpikir kritis. Kemampuan ini perlu diasah agar peserta didik meningkatkan "High order Thinking" mereka, sehingga peserta didik dapat meningkatkan kualitas diri mereka sendiri, membangun inovasi sendiri dan menjadi pemimpin yang efektif di masyarakat. Baik atau tidaknya suatu pemilihan model pembelajaran akan tergantung dengan tujuan pembelajaran, kesesuaian dengan materi pembelajaran, tingkat perkembangan peserta didik, kemampuan guru dalam mengelola pembelajaran serta mengoptimalkan sumber-sumber belajar yang ada (Daryanto, 2012:240). Penggunaan model pembelajaran yang tepat dapat mendorong tumbuhnya rasa senang terhadap proses pembelajaran, menumbuhkan dan meningkatkan motivasi dalam mengerjakan tugas, dan memberikan kemudahan bagi peserta didik untuk memahami pelajaran yang dianggap sulit. Beberapa model pembelajaran yang bisa diterapkan dalam pembelajaran dan dijadikan sebagai pilihan oleh guru dalam melaksanakan pembelajaran di kelas. Salah satu model pembelajaran yang cocok untuk pengembangan kemampuan HOTS peserta didik khususnya berpikir kritis 
adalah model pembelajaranConnecting Organizing Reflecting Extending (CORE).

CORE (connecting, organizing, reflecting, extending) merupakan salah satu model pembelajaran yang menggunakan pendekatan konstruktivisme dengan kegiatan pembelajaran berpusat pada peserta didik dan guru bertindak sebagai fasilitator. Hal tersebut didukung oleh Tamalene (2010) model pembelajaran CORE adalah salah satu model pembelajaran yang belandaskan pada teori konstruktivisme bahwa peserta didik harus dapat mengkonstruksikan pengetahuannya sendiri, melalui interaksi diri dengan lingkungannya Chambliss \& Calfee dalam Safitri (2014) menyatakan bahwa model CORE merupakan suatu model pembelajaran yang dapat mempengaruhi perkembangan berpikir kritis peserta didik dengan cara melibatkan peserta didik melalui kegiatan menghubungkan pengetahuan lama dengan pengetahuan baru dan antarkonsep (connecting), mengorganisasikan (organizing) pengetahuan baru dengan pengetahuan lama kemudian memikirkan konsep yang sedang dipelajari (reflecting) serta diharapkan peserta didik dapat memperluas pengetahuan mereka selama proses belajar mengajar berlangsung (extending). Sejalan dengan Safitri, Curwen, dkk (2010) menyatakan bahwa model CORE menggabungkan empat elemen penting dari konstruktivisme yaitu koneksi pengetahuan, organisasi informasi, refleksi, dan perluasan pengetahuan.Model CORE diharapkan mampu menjadi salah satu solusi untuk meningkatkan kemampuan berpikir kritis peserta didik

Menurut Shomad (2014), model pembelajaran CORE (connecting, organizing, reflecting, extending) adalah model pembelajaran yang menekankan kemampuan berpikir peserta didik untuk menghubungkan, mengorganisasikan, mendalami, mengelola, dan mengembangkan informasi yang didapat. Kegiatan menghubungkan konsep/informasi lama dengan konsep/informasi baru peserta didik dilatih untuk mengingat konsep/informasi lama dan menggunakan konsep/informasi lama untuk digunakan dalam konsep/informasi baru.

Oleh karena itu, maka dilakukan penelitian dengan judul "Pengaruh Model CORE Terhadap Hasil Belajar Matematika Ditinjau Dari Kemampuan Berpikir Kritis Peserta Didik Kelas V Gugus 02 Kuta Utara Kabupaten Badung 2019/ 2020".

\section{METODE}

Penelitian yang akan dilaksanakan ini termasuk jenis penelitian eksperimen. Berdasarkan beberapa jenis desain eksperimen yang ada, peneliti ini menggunakan quasi exsperimental design atau exsperimen semu. Maksud dari desain ini yaitu desain yang mempunyai kelompok control, tetapi tidak dapat berfungsi sepenuhnya untuk mengontrol variabel-variabel luar yang mempengaruhi pelaksanaan exsperimen. Penelitian ini dilakukan untu mengetahui ada tidaknya pengaruh antara variabel bebas melalui model pembelajaran CORE pada kelompok eksperimen dan pembelajaran konvensional pada kelompok kontrol terhadap hasil belajar matematika setelah mendapatkan perlakuan.

Rancangan yang digunakan dalam penelitian ini adalah factorial design (rancangan faktorial) $2 \times 2$. Penelitian ini menggunakan rancangan analisis varians dua jalur dengan faktor pemilah sebagai variabel moderator yaitu kemampuan berpikir kritis. Peserta didik akan dibagi menjadi dua kelompok yaitu peserta didik dengan kemampuan berpikir kritistinggi dan kemampuan berpikir kritis rendah.

Populasi penelitian ini adalah peserta didik Kelas V semester genap Sekolah Dasar Gugus 02 Kuta Utara. Sebelum dilakukan pengambilan sampel, terlebih dahulu dilakukan uji kesetaraan kelas. Berdasarkan hasil uji kesetaraan tersebut selanjutnya dilakukan teknik random sampling untuk memilih empat kelas digunakan sampel penelitian. Berdasarkan random sampling yang telah dilakukan, didapatkan hasil bahwa kelas $\mathrm{V}$ SD 4 Canggu dan VA SD 2 Tibubeneng sebagai kelompok eksperimen, sedangkan kelas VB dan VC SD 2 Tibubenenb sebagai kelompok kontrol.

Setelah dipilih kelompok eksperimen dan kontrol, selanjutnya dicari 33\% 
kelompok yang memiliki keterampilan berpikir kritis tinggi dan 33\% kelompok yang memiliki keterampilan berpikir kritis rendah. Adapun hasilnya adalah sebagai berikut.

Tabel 1. Sampel Penelitian (Model

Pembelajaran)

\begin{tabular}{ccc}
\hline $\begin{array}{c}\text { Kemampuan } \\
\text { Berpikir } \\
\text { Kritis }\end{array}$ & Core & Konvensional \\
\hline Tinggi & 19 & 19 \\
Rendah & 19 & 19 \\
\hline
\end{tabular}

Prosedur penelitian ini menggunakan

beberapa tahapan. Secara umum penelitian ini terdiri dari tiga tahapan. Adapun tahapan pada penelitian ini yaitu persiapan, pelaksanaan, dan tindak lanjut.

Variabel bebas dalam penelitian ini adalah model pembelajaran CORE dan pembelajaran konvensional. Pembelajaran model CORE melibatkan peserta didik kelompok eksperimen, sedangkan pembelajaran konvensionalmelibatkan peserta didik kelompok kontrol.

Variabel moderator dalam penelitian ini adalah kemampuan berpikir kritis. Kemampuan berpikir kritis dibagi menjadi dua yaitu kemamupuan berpikir kritis tinggi dan kemampuan berpikir kritis rendah. Tujuan dari penggunaan kemampuan berpikir kritis sebagai variabel moderator adalah untuk mengetahui dampak yang ditimbulkan dari kemampuan berpikir kritis terhadap hasil belajar matematika melalui penerapan model pebelajaran CORE.

Sedangkan variabel terikat pada penelitian ini adalah hasil belajar matematika pada peserta didik kelas V SD Gugus 02 Kuta Utara yang ditunjukkan oleh skor tes akhir peserta didik.

Data yang diperoleh dari hasil penelitian dideskripsikan menurut masingmasing variabel yaitu (1) deskripi data hasil belajar matematika melalui pembelajaran model CORE, (2) deskripsi data hasil belajar matematika peserta didik melalui pembelajaran konvensional, (3) deskripsi data hasil belajar matematika peserta didik yang memiliki kemampuan berpikir kritis rendah yag dibelajarkan dengan model CORE, (4) deskripsi hasil belajar matematika peserta didik yang memiliki hasil belajar rendah yang dibelajarkan dengan model CORE, (5) deskripsi data hasil belajar matematika peserta didik yang memiliki kemamupuan berpikir kritis tinggi yang dibelajarkan dengan pembelajaran konvensional, (6) deskripsi data hasil belajar matematika peserta didik yang memiliki kemampuan berpikir kritis rendah yang dibelajarkan dengan pembelajaran konvensional. Setelah data dideskripsikan selanjutnya dilanjutkan dengan pengujian hipotesis.

\section{HASIL DAN PEMBAHASAN}

1. Terdapat Pengaruh yang Signifikan Implementasi Model Core Terhadap Hasil Belajar Matematika Pada Peserta Didik Kelas V SD Gugus 02 Kuta Utara Kabupaten Badung

Pengujian hipotesis pertama mendapatkan harga Fhitung $=18,693$ sedangkan harga Ftabel pada dka $=1$ dan $\mathrm{dk}$ dalam $=72$ untuk taraf signifikansi 0,05 $=4,00$ hal ini berarti Fhitung lebih besar Ftabel ( $F h=18,693>F t=4,00)$. Hasil di tersebut mengindikasikan hipotesis nol $\left(\mathrm{H}_{0}\right)$ yang menyatakan tidak terdapat perbedaan yang signifikan hasil belajar Matematika antara peserta didik yang mengikuti model Core dengan peserta didik yang mengikuti model pembelajaran konvensional ditolak. Sebaliknya, hipotesis alternative $\left(\mathrm{H}_{1}\right)$ yang menyatakan terdapat perbedaan yang signifikan hasil belajar Matematika antara peserta didik yangmengikuti model Core dengan peserta didik yang mengikuti model pembelajaran konvensional, dinyatakan diterima.

Selanjutnya dilihat dari nilai rerata Hasil Belajar Matematika antara peserta didik yang mengikuti model Core sebesar 40,11 lebih tinggi dari pada nilai rerata Hasil Belajar Matematika antara peserta didik yang mengikuti pembelajaran konvensional sebesar 37,18, maka dengan demikian terdapat pengaruh model pembelajaran dengan Hasil Belajar Matematika antara peserta didik yangmengikuti model pembelajaran, dimana model Core memiliki pengaruh yang lebih baik dibandingkan dengan model pembelajaran konvensional.

Hasil penelitian ini sejalan dengan hasil penelitian yang dilakukan oleh Syahrir dan Meike pada tahun 2017 dengan judul Pengaruh Model 
Pembelajaran Core (Connecting, Organizing, Reflecting, Extending) Terhadap Peningkatan Hasil Belajar Siswa Dalam Materi Cahaya Pembelajaran IPA Kelas V SD Negeri 3 Cisantana. Dalam penelitiannya disimpulkan bahwa hipotesis yang menyatakan terdapat pengaruh Model Pembelajaran CORE terhadap peningkatan hasil belajar siswa dalam materi cahaya pembelajaran IPA di kelas V SD Negeri 3 Cisantana.

Proses berpikir peserta didik pada usia sekolah dasar sebagian besar melalui pengalaman langsung. Peserta didik juga sudah mampu untuk menggunakan pemikiran logika atau operasi dalam lingkup sederhana. Pada Pembelajaran model CORE, peserta didik diberi kebebasan dalam nmengembangkan pemikiran kritis matematikanya. Peserta didik diberi kesempatan untuk mengkoneksikan informasi lama dengan informasi yang baru (connecting), selanjutnya peserta didik mengorganisasikan informasi-informasi yang diperoleh seperti konsep apa yang diketahui, konsep apa yang dicari, dan keterkaitan antar konsep apa saja yang ditemukan (organizing), kemudian peserta didik diberi kesempatan untuk memikirkan kembali informasi yang didapat dan dipahami (reflecting), terakhir peserta didik dapat menggunakan pengetahuan tersebut dalam menyelesaikan sebuah masalah yang serupa dengan masalah sebelumnya (extending). Pembelajaran dengan model CORE membuat peserta didik mengkonstruksi pengetahuannya sendiri dengan didampingi oleh guru dan bukanlah terkesan pengetahuan dengan hafalan yang sebantardan akan perlahan terhapus dari memori peserta didik.

Berdasarkan pemaparan di atas, dapat disimpulkan bahwa terdapat pengaruh yang signifikan implementasi model core terhadap hasil belajar Matematika pada peserta didik kelas $\mathrm{V}$ SD gugus 02 Kuta Utara Kabupaten Badung.

2. Terdapat Pengaruh Interaksi yang Signifikan Model CORE dengan Kemampuan Berpikir Kritis terhadap Hasil Belajar Matematika pada
Peserta Didik Kelas V SD Gugus 02 Kuta Utara Kabupaten Badung

Pengujian hipotesis kedua mendapatkan harga Fabhitung $=128,478$ nilai Ftabel $=4,00$. Hal ini menunjukan bahwa Fhitung $>$ Ftabel, maka $\mathrm{H}_{0}$ ditolak dan $\mathrm{H}_{1}$ diterima, yang berarti bahwa terdapat pengaruh interaksi antara model pembelajaran dengan kemampuan berpikir kritis terhadap Hasil Belajar Matematika peserta didik.

Penelitian ini sejalan dengan penelitian yang dilakukan oleh Wati, dkk pada tahun 2019 dengan judul Pengaruh Model Pembelajaran Core (Connecting Organizing Reflecting Extending) Untuk Meningkatkan Keterampilan Berpikir Kritis Siswa. Berdasarkan hasil penelitian dapat disimpulkan bahwa; 1) Ada pengaruh model pembelajaran CORE (Connecting Organizing Reflecting Extending) terhadap keterampilan berpikir kritis siswa yang dibuktikan nilai uji t sampel berpasangan, nilai $-\mathrm{t}_{\text {hitung }}<\mathrm{t}_{\text {tabel }}<\mathrm{t}_{\text {hitung }}$ yakni 23,013 $<$ $2,05553<23,013$ maka $H_{1}$ diterima, 2) Keterampilan Berpikir kritis siswa setelah diterapkan model CORE mengalami peningkatan yang dibuktikan dari rata-rata nilai $\mathrm{N}$-Gain sebesar 0,55 dengan kriteria sedang.

Keaktifan peserta didik dalam membangun pengetahuannya untuk memecahkan masalah yang dihadapi. Hal ini sesuai dengan teori perkembangan kognitif yaitu anak SD memasuki tahap operasional konkret, pada tahap ini peserta didik akan lebih mudah memahami materi jika ia aktif melaksanakannya sendiri. Keaktifan peserta didik membangun pengetahuannya dalam pembelajaran yang dapat muncul melalui diskusi, praktikum, dan pemecahan suatu masalah. Dalam membangun pengetahuannya, peserta didik tentu selalu melalui proses berpikir. Model pembelajaran CORE dapat digunakan untuk mengaktifkan peserta didik dalam membangun pengetahuannya sendiri melalui empat tahapan pokok yaitu connecting, organizing, reflecting, extending.

Pembelajaran dengan model CORE dan berpikir kritis memiliki interaksi 
terhadap hasil belajar matematika peserta didik. Pada peserta didik yang memiliki kemampuan berpikir kritis tinggi, hasil belajar matematika peserta didik yang mengikuti pembelajaran model CORE lebih baik daripada peserta didik yang mengikuti pembelajaran konvensional. Pembelajaran dengan model CORE menjadikan peserta didik sebagai subjek dalam aktivitas pembelajaran (studentcenter). Hal ini memberikan kesempatan pada peserta didik untuk membangun pengetahuannya sendiri sehingga dapat mengoptimalkan hasil belajarnya. Pembelajaran tidak dimulai dengan presentasi kebenaran tapi dengan menciptakan kesempatan untuk mendorong pemikiran peserta didik sendiri. Peserta didik dengan kemampuan berpikir kritis tinggi akan menunjukkan sikap yang lebih aktif dan antusian untuk mengikuti pembelajaran yang membutuhkan keaktifan peserta didik.

Sedangkan pada peserta didik yang memiliki kemampuan berpikir kritis rendah, hasil belajar matematika peserta didik yang mengikuti pembelajaran konvensional akan lebih baik daripada peserta didik yang mengikuti pembelajaran CORE. Hal ini karena peserta didik dengan kemampuan berpikir kritis rendah biasanya memilih untuk mengikuti kebenaran atau konsep yang langsung disajikan guru daripada membangun sendiri pengetahuannya. Sesuai dengan macam intelegensi menurut ahli yaitu kemampuan seseorang untuk memecahkan persoalan dan menghasilkan produk dalam berbagai situasi.

Berdasarkan pemaparan di atas, dapat disimpulkan bahwa terdapat pengaruh interaksi yang signifikan model core dengan kemampuan berpikir kritis terhadap hasil belajar Matematika pada peserta didik kelas V SD gugus 02 Kuta Utara Kabupaten Badung.

3. Pada Kelompok Peserta Didik yang Memiliki Kemampuan Berpikir Kritis Tinggi, Terdapat Pengaruh yang Signifikan Implementasi Model Core Terhadap Hasil Belajar Matematika pada Peserta Didik Kelas V SD

\section{Gugus 02 Kuta Utara Kabupaten Badung}

Berdasarkan pengujian hipotesis ketiga, menunjukkan nilai thitung sebesar 21,55 , sedangkan nilai t hitung lebih besar daripada $t$ tabel pada taraf signifikan $5 \%$ sehingga $\mathrm{H}_{0}$ ditolak dan $\mathrm{H}_{1}$ diterima. Hal ini mengindikasikan bahwa kelompok peserta didik yang memiliki kemampuan berpikir kritis tinggi, terdapat perbedaan yang signifikan pada hasil belajar Matematika antara kelompok peserta didik yang mengikuti pembelajaran dengan model Core dengan kelompok peserta didik yang mengikuti pembelajaran dengan model pembelajaran konvensional. Selanjutnya pada $u j i ~ t$ scheffe mengindikasikan bahwa kelompok peserta didik yang memiliki kemampuan berpikir kritis tinggi dengan model Core hasil belajarnya lebih baik daripada dengan model pembelajaran konvensional.

Peserta didik di usia sekolah dasar akan lebih memahami materi dengan baik jika peserta didik dilibatkan langsung. Sesuai dengan teori konstruktivisme, pengetahuan secara aktif diterima orang melalui indra atau melalui komunikasi atau pengalaman..Pembelajaran dengan model CORE menjadikan peserta didik sebagai subjek dalam pembelajaran (studentcenter) dengan memberikan kesempatan kepada peserta didik untuk beraktivitas untuk membangun, mengaitkan, mengaplikasikan konsep yang baru dengan konsep lama. Pembelajaran tidak dimulai dengan presentasi kebenaran tapi dengan menciptakan kesempatan kepada peserta didik untuk mendorong pemikiran sendiri. Peserta didik yang memiliki kemampuan berpikir kritis tinggi akan menunjukkan sikap antusias dan aktif dalam mengikuti pembelajaran.

Berdasarkan pemaparan di atas, dapat disimpulkan bahwa pada kelompok peserta didik yang memiliki kemampuan berpikir kritis tinggi, terdapat pengaruh yang signifikan implementasi model core terhadap hasil belajar matematika pada peserta didik kelas V SD Gugus 02 Kuta Utara Kabupaten Badung. 
4. Pada Kelompok Peserta Didik yang Memiliki Kemampuan Berpikir Kritis Rendah, Terdapat Pengaruh yang Signifikan Implementasi Model Core Terhadap Hasil Belajar Matematika pada Peserta Didik Kelas V SD Gugus 02 Kuta Utara Kabupaten Badung

Berdasarkan pengujian hipotesis ketiga, menunjukkan nilai nilai thitung sebesar 9,65, sedangkan nilai t hitung lebih besar daripada $t$ tabel pada taraf signifikan $5 \%$ sehingga $\mathrm{H}_{0}$ ditolak dan $\mathrm{H}_{1}$ diterima. Hal ini berarti untuk kelompok peserta didik yang memiliki kemampuan berpikir kritis rendah, terdapat perbedaan yang signifikan pada hasil belajar Matematika antara kelompok peserta didik yang mengikuti pembelajaran dengan model Core dengan kelompok peserta didik yang mengikuti pembelajaran dengan model pembelajaran konvensional.

Kemampuan peserta didik tentu mempunyai perbedaan dalam sebuah kelas. Peserta didik yang memiliki kemampuan berpikir kritis rendah kurang menunjukkan sikap aktif dalam pembelajaran. Kelompok ini akan cenderung menerima dan mengikuti arahan dari guru. Penerapan pembelajaran model CORE akan sulit diterima oleh peserta didik di kelompok ini. Peserta didik akan mengalami beberapa kendala dalam aktivitas mengkoneksikan informasi lama dengan informasi yang baru (connecting), selanjutnya mengorganisasikan informasi-informasi yang diperoleh seperti konsep apa yang diketahui, konsep apa yang dicari, dan keterkaitan antar konsep apa saja yang ditemukan (organizing), memikirkan kembali informasi yang didapat dan dipahami (reflecting), serta menggunakan pengetahuan tersebut dalam pemecahan masalah yang serupa dengan masalah sebelumnya (extending). Tahapan CORE ini belum dapat diterima secara utuh oleh peserta didik yang memiliki kemampuan berpikir kritis rendah karena peserta didik belum memiliki cukup pengetahuan awal untuk melakukan kegiatan connecting.

Peserta didik ini belum tentu termasuk kategori kemampuan lemah/ rendah. Pada teori intelegensi telah dijelaskan bahwa terdapat berbagai kemampuan yang salah satunya dapat terjadi pada peserta didik. Perbedaan ini dapat menjadi salah satu menjadi faktor kesulitan peserta didik untuk membangun pengetahuannya sendiri seperti yang diminta pada tahapan CORE. Selain itu terdapat pula kesulitan belajar lain yang datang dari dalam diri peserta didik seperti kurangnya kemampuan dasar yang dimiliki peserta didik, kurangnya bakat khusus dalam situasi belajar tertentu, dan situasi pribadi peserta didik. Sehingga peserta didik lebih memilih untuk mendengarkan penjelasan dari guru untuk menyelesaikan masalah matematika. Maka dapat disimpulkan bahwa hasil belajar peserta didik yang memiliki kemampuan berpikir kritis rendah yang belajar melalui penerapan CORE lebih rendah dibandingkan dengan peserta didik yang belajar melalui pembelajaran konvensional.

Implikasi dari penelitian ini adalah sebagai berikut.

1. Model Core pada penelitian ini terbukti efektif berpengaruh terhadap hasil belajar matematika peserta didik, sehingga model ini dapat dipakai rujukan bagi pendidik untuk menerapkannya pada pembelajaran Matematika.

2. Model Core pada penelitian ini terbukti efektif berpengaruh pada siswa siswa yang memiliki kemampuan berpikir kritis tinggi, sehingga model ini dapat dipakai rujukan bagi pendidik agar menerapkannya pada siswa yang ingin tantangan dan memiliki kreativitas tinggi dalam belajar.

\section{PENUTUP}

Berdasarkan penelitian yang telah dilakukan, dapat disimpulkan beberapa hal sebagai berikut.

1) Terdapat pengaruh yang signifikan implementasi Model CORE terhadap hasil belajar matematika pada peserta didik Kelas V SD Gugus 02 Kuta Utara Kabupaten Badung.

2) Terdapat pengaruh interaksi yang signifikan Model CORE dengan 
kemampuan berpikir kritis terhadap hasil belajar matematika pada peserta didik Kelas V SD Gugus 02 Kuta Utara Kabupaten Badung.

3) Pada kelompok peserta didik yang memiliki kemampuan berpikir kritis tinggi, terdapat pengaruh yang signifikan implementasi Model CORE terhadap hasil belajar matematika pada peserta didik Kelas V SD Gugus 02 Kuta Utara Kabupaten Badung.

4) Pada kelompok peserta didik yang memiliki kemampuan berpikir kritis rendah, terdapat pengaruh yang signifikan implementasi Model CORE terhadap hasil belajar matematika pada peserta didik Kelas V SD Gugus 02 Kuta Utara Kabupaten Badung.

Berdasarkan simpulan yang telah dipaparkan dapat disampaikan beberapa hal sebagai berikut.

Peserta didik disarankan untuk selalu mengembangkan wawasannya, sehingga kemampuan berpikir kritis siswa dapat optimal. Hal ini akan dapat menunjang hasil belajar siswa.

Guru disarankan untuk selalu berinovasi menggunakan pembelajaran inovatif dalam pembelajaran, sehingga membuat siswa bersemangat dan termotivasi dalam belajar.

Dinas pendidikan disarankan untuk selalu mendukung upaya peningkatkan profesionalisme guru, terutama dalam mengadakan kegiatan-kegiatan yang menunjang proses pembelajaran di sekolah.

Peneliti lain disarankan untuk mengembangkan penelitian ini, agar kendala yang dihadapi dalam dunia pendidikan dapat diminimalkan.

\section{DAFTAR RUJUKAN}

Daryanto. 2012. Model Pembelajaran Inovatif. Yogyakarta: Gava Media.

Dimyati dan Mudjiono. 2006. Belajar dan Pembelajaran. Jakarta: Rineka Cipta.

Ennis, Robert. 2011. The Nature of Critical Thinking : An Outline of Critical Thinking Dispositions and Abilities, [Online]. Tersedia: http://faculty.ed.uiuc.edu/rhennis/. Diakses pada tangal 2 Januari 2020
Gokhale, A.A.1995. Collaborative Learning Enhances Critical Thinking. Journal of Technology Education, 7(1).

Gunawan. 2003. Genius Learning Strategy. Jakarta: Gramedia.

Poerwadarminta, W.J.S. 2004. Kamus Besar Bahasa Indonesia. Balai Pustaka. Jakarta.

Safitri, D, dkk. 2014. Penerapan Model CORE untuk meningkatkan Kreativitas dan Hasil Belajar Sejarah Peserta Didik Kelas X3 SMAN 1 Bojonegoro TA 2013/2014. Jurnal Edukasi Vol. 1 No. 2.

Shomad, Zahid. (2014). Keefektifan Model Pembelajaran CORE dan Pairs Check terhadap Kemampuan Penalaran Matematis Siswa Kelas VII Semarang

Suherman, E.,dkk. 2003. Strategi Pembelajaran Matematika Kontemporer. Bandung: JICA.

Suherman. E. 2001. Pembelajaran Matematika Kontemporer. Bandung: JICA.

Suprijono, A. 2016. Model-model Pembelajaran Emansipatoris. Yogyakarta: Pustaka Pelajar.

Syahrir, Dede Cahyati dan Meike IImada. 2017. Pengaruh Model Pembelajaran Core (Connecting, Organizing, Reflecting, Extending) Terhadap Peningkatan Hasil Belajar Siswa Dalam Materi Cahaya Pembelajaran IPA Kelas V SD Negeri 3 Cisantana. Jurnal Lensa Pendas Prodi PGSD Vol. 2 No. 2.

Tu'u, 2012. Pengertian Hasil Belajar Menurut Para Ahli. www.scribd.com

Wati, Karlina, dkk. 2019. Pengaruh Model Pembelajaran Core (Connecting Organizing Reflecting Extending) Untuk Meningkatkan Keterampilan Berpikir Kritis Siswa. Jurnal Natural Science Education Research Vol. 1 No. 2. 